\title{
Scaling up renewable energy in Africa: measuring wind energy through econometric approach
}

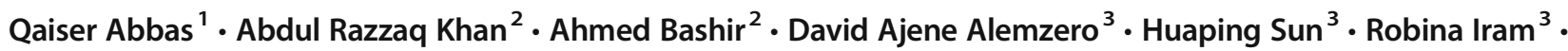 \\ Nadeem Iqbal $^{4}$
}

Received: 28 February 2020 / Accepted: 4 June 2020 / Published online: 18 June 2020

(C) Springer-Verlag GmbH Germany, part of Springer Nature 2020

\begin{abstract}
Wind energy continues to make inroads in Africa due to falling costs and technological advancements. Most African countries are planning, exsiccating and connecting their renewable energy projects with national grid system with giving high propriety to energy security, sustainable energy consumption and low carbon emission. Many policies have been enacted by countries to promote the scaling up of wind energy and renewable energy in particular, across the globe. However, these policies have mixed effects on the deployment of wind energy. For this purpose, current study used panel data and fixed effects model for 17 African countries with wind installed generation capacity to determine the driver of wind energy development on the African continent between 2008 and 2017. The variables were grouped into three thematic areas: policy, socioeconomic, and country-specific factors. After conducting the analysis, socioeconomic variables (GDP, $\mathrm{CO}_{2}$, energy use) and energy security variables (energy import, electricity consumption) have significant effects in determining the scaling up of wind energy in Africa. However, the policy variables of FITs, licensing during, and Tax did not have significant effects on wind energy capacity addition for the case of Africa. This study adds to the drivers of nascent wind energy deployment literature in Africa. This study suggests that set of effecitive policies are deem necessary to scale up wind energy in Africa.
\end{abstract}

Keywords Renewable energy $\cdot$ Wind energy $\cdot$ Electricity $\cdot \mathrm{CO}_{2} \cdot$ Scaling up

\section{Nomenclature}

RETS renewable energy technologies

FITs feed in tariffs

GDP gross domestic product

$\mathrm{CO} 2 \quad$ carbon dioxide
PIDA African Union's Programme for Infrastructure Development in Africa

GWEC Global Wind Energy Council

DTU Denmark Technical University

AREI Africa Renewable Energy Initiative

Responsible Editor: Philippe Garrigues

Qaiser Abbas

Qabbas@gudgk.edu.pk

Abdul Razzaq Khan

abdul.razzaq@ajku.edu.pk

Ahmed Bashir

Ahmeded_abc39@yahoo.com

David Ajene Alemzero

awelingazure@gmail.com

Huaping Sun

shp@ujs.edu.cn

Robina Iram

Robinairam22@yahoo.com
Nadeem Iqbal

drnadeemiqbal1@gmail.com

1 Department of Economics, Ghazi University Dera Ghazi Khan, Dera Ghazi Khan, Pakistan

2 Department Sociology and Rural Development, University of AJ\&K, Muzaffarabad, Pakistan

3 School of Finance and Economics, Jiangsu University, Zhenjiang 212013, China

4 Faculty of Management Sciences, Ghazi University Dera Ghazi Khan, Dera Ghazi Khan, Pakistan 


$\begin{array}{ll}\text { MW } & \text { Megawatts } \\ \text { SEWEA } & \text { South Africa Wind Energy Association } \\ \text { REIPPP } & \begin{array}{l}\text { Renewable Energy Independent Power } \\ \text { Procurement Program }\end{array} \\ \text { IRENA } & \begin{array}{l}\text { International Renewable Energy Agency } \\ \text { IMF }\end{array} \\ \text { The International Monetary Fund } \\ \text { RD\&D } & \text { research development and demonstration } \\ \text { VRE } & \text { variable renewable energy } \\ \text { C O V I D -Coronavirus }\end{array}$

19

\section{Introduction}

Wind energy is an infant industry in Africa while growing rapidly in Europe and other developed area of the world this source of energy (wind). It is one of the renewables energy that can aid Africa to meet its numerous energy needs for rapid population growth, urbanization, and can help to meeting the Paris Accord of halting global temperature rise above $1.5^{\circ}$ preindustrial levels. This wind energy can enhance Africa capability to deliver cleaner, cheaper, and environmentally friendly energy with ensuring energy security, creating energy economy and reducing energy poverty (Mohsin et al. 2019b; Mohsin et al. 2018b; Mohsin et al. 2018a; Iqbal et al. 2019). Most African countries face these challenges of growing energy demand, oil price volatility, $\mathrm{CO}_{2}$ emissions levels, and national security risks due to overly consumption of fossil fuels (Moerenhout et al. 2019). Despite these compelling reasons for Africa to scale up wind energy on the continent, the installed capacity of wind on the continent was paltry amount of $5464 \mathrm{MW}$ in 2018 (Asim et al. 2020). Today, Africa is sharing about $1 \%$ of the total global installed wind capacity. However, there has been a political commitment from the heads of states to scale up renewable energy sources (RES) on the continent with the formation of the Africa Renewable Energy Initiative (AREI), which aims to scale up RES capacity to achieve the sustainable development goals, by leapfrogging Africa to a low carbon development economy and economic growth. This initiative aims to install $10 \mathrm{GW}$ by 2020 and $300 \mathrm{GW}$ by 2030 (AREI 2017). There are laudable initiatives aimed at scaling up wind and renewable energy technologies (RETs) in general Africa: The Africa-EU Partnership program, the African Union's Programme for Infrastructure Development in Africa (PIDA), Power Africa, the Africa Clean Energy Corridor and as well as multilateral, bilateral and civil commitments to scaling up wind energy on the continent (Ahmed and Bhatti 2019).

In the course of the decade, Africa's population is expected to grow at $3 \%$ per annum, while its gross domestic product (GDP) would increase only by $1.4 \%$ until 2030 (GWEC Africa Wind Energy Handbook, 2019). However, even this growth cannot be achieved and sustained unless there are reliable, accessible, and cheaper sources of energy to meet the demands of an increasing population. In Sub-Saharan Africa, only $48 \%$ have access to electricity; this is hindering the advancements in their socioeconomic well-beings such as education, health delivering, access to clean water, and food. According to the first continental report of the implementation 2063 Agenda, household access to electricity has increased nominally to $63 \%$ in 2019 continent wide. Furthermore, for the continent to industrialize and create shared prosperity and transform the various sectors of the continent's economic structure, the role of energy is very important. Africa today generates about $81 \%$ of its electricity from thermal sources, which is very expensive and creates macroeconomic instability in many countries due to the import-based electricity generation (Morales and Hanly 2018). So, this is not good for both economic as well as environment. Thus, mitigating these unbearable situations, wind energy is the panacea for them. It is the source of energy that can help Africa leapfrog to a sustainable electricity generation.

This study aims to contribute to existing research in many ways. First and for most, it uses an econometric approach to assess the determinants of scaling up wind energy on 17 African countries with wind installed generation capacity, using four thematic variables such as socioeconomic factors, energy security, policy factors, and country-specific factors. These factors have been further subdivided into GDP, energy import, energy use, and electricity consumption from non-fuel sources, wind capacity, $\mathrm{CO} 2$ Emissions levels, and electricity consumption. This study will contribute to a growing literature on the drivers of wind energy deployment on the African continent.

Secondly, the study focuses on the entire African continent, unlike Ogbe and Ogbe (2018); Komendantova et al. (2019); and Mukasa et al. (2015) who studied only Sub-Saharan Africa (SSA) and focused only on all RES, not wind energy only. This gap in literature gives the opportunity to analyze a full length of policy instruments such as tax incentives, FITs relevant to the deployment of wind energy on the African continent. The time period for this study has been taken between 2008 and 2017; while existing studies used not much longer time period. Finally, under the analysis using an econometric model, a panel data fixed effect technique was used to determine the effects of policy instruments and exogenous variables on the deployment of wind energy on the African continent. The fixed effect technique was applied because of the time-invariant geographic factor (country) that could correlate with the exogenous variables (Mohsin et al. 2019d; Mohsin et al. 2019a). The study, therefore, confirms that GDP, energy use, energy import, electricity consumption, $\mathrm{CO} 2$, and electricity from the non-fuel sources are very significant in determining the scaling up of wind energy on the African continent. Surprisingly, none of the dummies for the 
policy instrument was significant in scaling up wind energy on the African continent. They had varied magnitudes of direction for their coefficients. These results are identical with several previous studies such as (Zhang et al. 2018), (Bublitz et al. 2019) and (Ahmadi et al. 2020). The study is expected to provide a wider perspective on discourse regarding scaling up wind energy on the African continent to meet growing energy needs.

The rest of the paper is organized as follows: "Model for wind energy development in Africa" section gives a background to the study; "Data and methodology" section is research and methodology. The results of the panel model econometrics analyses are described in "Results and discussion" section. "Conclusion and policy implication" section ends the paper with conclusions and recommendations.

\section{Model for wind energy development in Africa}

From the model below, it explains how integrated the various energy systems are in meeting the energy needs of African countries. The quantum of national resources, prices of crude at the global markets, energy demand, and the demand for energy services are exogenous to the model. The Africa continent is endowed with a lot of natural resources, which serve as a source of foreign exchange for them when they are exploited. These are fossil fuels like oil and gas, coal, etc. In the case of fossil fuels, it has subjected them to price volatility in the global markets, leaving most economies worse off (Asbahi et al. 2019; Sun et al. 2019a, b). Those who do not have it, spend a huge amount of hard currencies to import it for powering their economies, and facing macroeconomic instability in the long run. For Instance, Ghana was projected to spend over a billion dollars in 2019 to import crude to power its thermal plants (Government of Ghana, 2019). For Africa to move to a sustainable future, it has to develop its renewables resources, which are local, abundant, and cheaper than fossil fuels. But generating energy from this VRE comes with system challenges (Olsen et al. 2020), known as the integration challenges and needs system planning and management to ensure its efficient adequate to generate to meet demand at the least the costs (Iram et al. 2019; Sun et al. 2020a; and Sun et al. 2020b). On the other hand, the green boxes are endogenous to the model, that is, residential, transport, public services, power, oil, and gas models are all given in the model. The endogenous variables in the model have to adapt energy efficiency to consume electricity to ensure that the system is maintained. Actors in the electricity sector in Africa can ensure demand side responses like behind the meter solutions are implemented; consumers can use the smarter meter and purchase energy efficient products in the market. On the part of transport, Africa can build infrastructure for electric vehicles (EVs) that will do away with higher transport fares in the cities and electrify all public transport. Industry individuals can undertake distributed wind generation to free the grid of pressure and ensure regular supply and energy security. African countries need to modernize their tariffs' deigns as a demand response tool to ensure optimal energy consumption without any backlash from customers (Zhou et al. 2020). Figure 1 shows the overall energy situation.

\section{Overview of the wind industry in Africa}

The wind industry in Africa is promising and looking forward. There is a growing number of African countries that have embraced wind energy and are taking practicable steps to generate power from this renewable source. For example, Egypt, Morocco, South Africa, Kenya, Ethiopia, and Tunisia are the leading economies which are driving wind capacity installation in Africa. The likes of Senegal, Ghana, Gambia, Chad, and Algeria are equally joining the wind bandwagon. There has been a political acceptance of RES in Africa and wind in general, with the establishment of the African Renewable Initiative (AREI) 2015. The drivers of wind energy in Africa are South Africa with $6360 \mathrm{MW}$ of power from wind by 2030, that is, $69 \%$ from the IPPs, as part of the Renewable Energy Independent Power Procurement Program (REIPPP) (SEWEA 2019). With 1.2.GW wind energy capacity, Morocco is another country which is driver of Wind energy on the African continent. The wind energy program which was launched in 2010, they have decided to enhance wind energy production capacity over 2000 MW till 2020 (Government of Morroco, 2019). Africa is Egypt, which is blessed with superb wind speed, especially around the Suez Canal, which is one of the best areas in the World for harnessing energy. The wind speed sometimes range between around 8 and $10 \mathrm{~m} / \mathrm{s}$ at height $100 \mathrm{M}$ (IRENA 2018). Egypt targets $40 \%$ of RES to make its energy matrix by 2035 .Under its distinctive feed-in, tariff program, which was launched in 2014,which seeks to encourage electricity generation from RES, targets $4300 \mathrm{MW}$ generation. Ethiopia's current wind installed capacity is 324 MW (IRENA 2019). Furthermore, Kenya is a regional leader in the Eastern Africa Power Pool, with $335 \mathrm{MW}$ installed capacity and another $350 \mathrm{MW}$ expected to be procured by 2023 (GWEC, 2019) (Table 1). Kenya has already awarded more than $1 \mathrm{GW}$ of wind capacity under its prevailing feed in tariff rate. Mauritania has a current installed capacity of 34 MW (Chen et al. 2017). However, the country is endowed with an excellent wind speed along its northern coastline between 8.3 and $8.7 \mathrm{~m} / \mathrm{s}$, this even increases to $9 \mathrm{~m} / \mathrm{s}$ in the Nouadhibou region (Mustapha et al. 2015).

\section{Framework for the determinants of wind energy deployment in Africa}

The framework above depicts the key variables used in the study. Each variable is being discussed in detail from the under listed. Certain key factors are vital drivers of wind energy development globally and in Africa, 


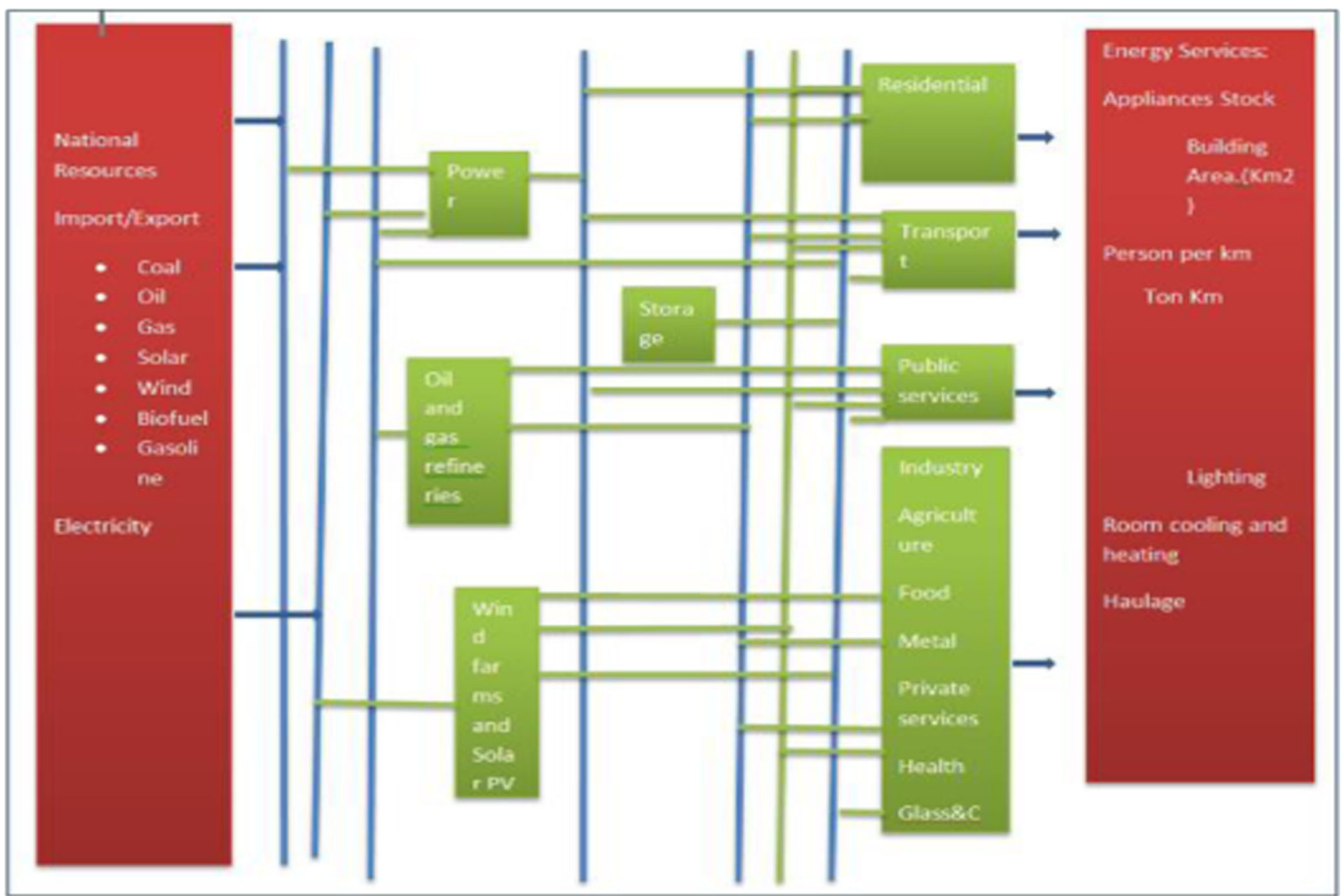

Fig. 1 Schematic diagram

particularly. These are grouped into three thematic areas: socioeconomic, political, and country wise factors, as done by Olanrewaju et al. (2019), Ogbe and Ogbe (2018), Kilinc-ata (2016), Thapar et al. (2018), Menz and Vachon (2006), Aguirre and Ibikunle (2014), and Marques et al. (2010). Zhao et al. (2020) categorized these into pricing and non-pricing policies influencing wind energy development in China. However, Panse and Kathuria (2018) argue that geographical, bureaucracy, technical, and societal factors determine the investments' firms that make into wind power than technology (WTP) in India. Figure 2 shows the wind development index.

\section{Policy factors}

\section{Public policies}

The dawn of the 1970s brought a significant development in the energy landscape, which saw increased oil prices, making nations started looking for alternative fuel sources. The oil price shocks were monumental and hence the push for the adoption of alternative renewable energy. The world has never looked back and adopted renewables to power homes. The Paris Accord of 2015, which was brought to being to help nations voluntarily and compulsorily commit to reducing global temperature below 1.5 pre-industrial levels, through their nationally determined contributions (NDCs), is another driver of the adoption of wind energy (Eickemeier et al. 2014). Prior to this, the 1970s were used for R\&D purposes; countries were investing and researching new technologies for scaling up renewable energy sources likewind and solar. Another way to increase the mass deployment of wind energy is to replace feed in tariffs with auctions, which is very effective for utility-scale wind farm projects (International Renewable Energy Agency (IRENA) 2017). Obligations and traded certificates were ubiquitous in the 2000s. Feed in tariff (FITS) has become the practice for many countries to scale up renewable energy deployment (Kilinc-ata 2016). According to Nicolini and Tavoni (2017), the tariff is effective in scaling up renewables; a $1 \%$ increase in tariffs leads to renewable generation between 18 and $26 \%$. Hence, this study expects that underlined variable to positively relate to wind capacity addition. Zhao et al. (2020) argued in that feeds in tariffs are the most effective means to scaling up RES, considering factors such as fairness, cost-efficiency, responsibility, by using the dynamic efficiency model. In addition, tax incentives are equally very important in scaling up wind energy. For instance, India's domestic tax law gives a 10-year tax holiday 
Table 1 Installed onshore wind capacity in Africa

\begin{tabular}{|c|c|c|c|c|c|c|c|c|c|c|}
\hline CAP (MW) & 2009 & 2010 & 2011 & 2012 & 2013 & 2014 & 2015 & 2016 & 2017 & 2018 \\
\hline Africa & 739 & 861 & 990 & 1124 & 1738 & 2396 & 3317 & 2396 & 3828 & 4570 \\
\hline \multicolumn{11}{|l|}{ Country } \\
\hline Algeria & & & & & & 10 & 10 & 10 & $10 \mathrm{e}$ & 10 \\
\hline Cabo Verde & 2 & 2 & 16 & 26 & 26 & 26 & 26 & 260 & 26 & 27 \\
\hline Chad & & & & & & & & 1 & 1 & 1 \\
\hline Egypt & 435 & 550 & 550 & 550 & 550 & 550 & 750 & 750 & 750 & 1125 \\
\hline Eritrea & 1 & 1 & 1 & 1 & 1 & 1 & 1 & 1 & 1 & 1 \\
\hline Ethiopia & 0 & 0 & 81 & 81 & 171 & 171 & 324 & 324 & 324 & 324 \\
\hline Gambia & 0 & 0 & 0 & 1 & 1 & 1 & 1 & 1 & 1 & 1 \\
\hline Ghana & & & & & & & 0 & 0 & 0 & 0 \\
\hline Kenya & 0 & 6 & 6 & 6 & 6 & 6 & 26 & 26 & 26 & 326 \\
\hline Madagascar & 0 & 0 & 0 & 0 & 0 & 0 & 0 & 0 & 0 & 0 \\
\hline Mauritania & & & & & 4 & 4 & 34 & 34 & 34 & 34 \\
\hline Mauritius & 1 & 1 & 1 & 1 & 1 & 1 & 1 & 11 & 11 & 11 \\
\hline Morocco & 221 & 221 & 225 & 225 & 495 & 797 & 797 & 897 & 1017 & 1220 \\
\hline Namibia & 0 & 0 & 0 & 0 & 0 & 0 & 0 & 0 & 0 & 5 \\
\hline Nigeria & 2 & 2 & 2 & 2 & 2 & 3 & 3 & 3 & 3 & 3 \\
\hline Reunion & 15 & 15 & 15 & 151 & 15 & 15 & 15 & 17 & 17 & 17 \\
\hline Seychelles & & & & & 6 & 6 & 6 & 6 & 6 & 6 \\
\hline Somalia & & & & 2 & 2 & 2 & 3 & & 4 & 4 \\
\hline South Africa & 8 & 10 & 10 & 10 & 257 & 569 & 1079 & 1473 & 2094 & 2094 \\
\hline Tunisia & 53 & 53 & 53 & 173 & 200 & 223 & 240 & 245 & 245 & 245 \\
\hline
\end{tabular}

to wind energy distribution and generation projects (Cox et al. 2015). In contrast, Texas (2019) disputed this view that production tax credit (PTC) is economically unviable and fundamentally distorts the markets and strains the grid. According to Iqbal and Mohsin 2019; and Mohsin et al. 2019c

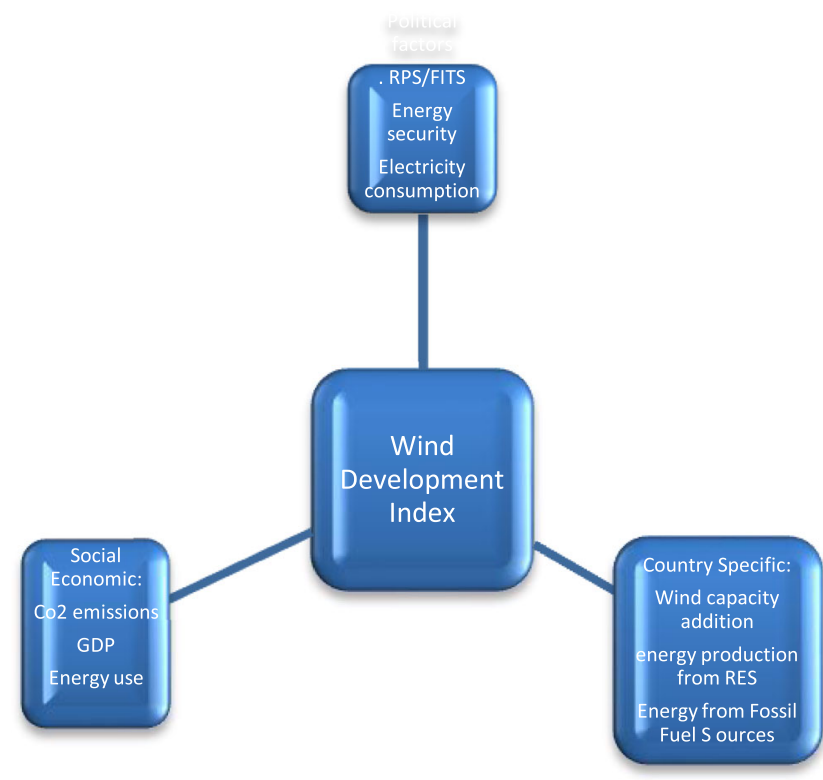

Fig. 2 Framework for the analysis of wind energy deployment in Africa the current PTC would cost the nation $\$ 40.12$ billion from 2018 to 2027.

\section{Energy security}

Energy security is defined as the low vulnerability of energy systems; the vulnerability of energy systems are viewed in three ways: robustness is reducing exposure to risks, such lack of resources, resilience is the ability of the system to recover from shocks, and sovereignty is when energy assets are being controlled by foreign actors (Jewell et al. 2016). Literature is replete with energy security being a necessary condition for countries to develop renewable energy, especially wind energy (Olanrewaju et al. 2019; and Olanrewaju et al. 2019). Energy import is used as a proxy for security. Implying, if the nation imports more of its energy, then it makes economic sense for the nation to diversify its energy mix to include wind energy, which is cost competitive and environmentally friendly. Wind energy, together with storage, can improve energy security by diversifying the energy mix and providing adequately and readily available electricity and fighting climate change (Eberhard and Dyson 2020). Due to the issue of drought caused by climate change in certain parts of Africa, affecting the water levels of dams for hydropower, storage technologies with fewer $\mathrm{CO} 2$ emissions could use renewables as a baseload for power generation (Eberhard and Dyson 
2020). Thus, this study anticipate energy security to positively correlate with wind capacity addition.

As far as electricity consumption keeps increasing, the question of energy security comes to mind. Electricity forms the foundation for sound industrialization in any country. Hence, Africa's industrialization can jump start the economies to growth trajectories, if they generate enough to meet the need of industries to promote economic growth and development (Olanrewaju et al. 2019). Wind energy is seen as one that can help to achieve this objective on the African continent with ease since the continent has the potential technically and economically to generate power from wind. Shami et al. (2016) concluded wind energy could be harnessed by Pakistan to meet its power needs in the midst of generation deficit. Renewable constitute $25 \%$ of global electricity and project to grow to $50 \%$ by 2030 and almost a quarter to $100 \%$ by mid-century (McKinsey and Company 2019).

\section{Socioeconomic factors and GDP}

Referencing earlier works by Marques, Fuinhas, and Manso (2010) and Aguirre and Ibikunle (2014) $\mathrm{CO}_{2}$ emissions level is used as a proxy for environmental factors. This is anticipated to have a direct correlation with wind capacity addition in Africa. Reducing emissions would help balance the socioeconomic system by redistributing social benefits coming from introducing a national carbon pricing system (Edenhofer et al. 2019). International monetary fund (IMF) recommended the use of revenue-neutral tax subsidies scheme to promote the generation of cleaner electricity like the wind in member countries without increasing fuel prices (Principle and Practice 2019). Africa's part of total global emissions levels is anticipated to increase from $3 \%$ to $23 \%$ by 2100 (Lucas et al. 2015). Africa must take steps to control its emission levels by using the clean development mechanism to generate its power from cleaner sources like wind (Purohit and Michaelowa 2007). However, Sei et al. (2016) contends that only about $2 \%$ of projects and $7 \%$ of certified emission reductions (CER) potential have the likelihood of reducing emissions and not overestimated. Thus, it satisfy the condition of "additionality concept."

Gross domestic growth (GDP) of a country determines the extent a country would invest in renewable energy and wind energy in particular. Countries with higher GDP are better off and have higher income levels and can afford to invest part of their GDP to wind or electricity consumption. Higher the GDP growth rate of a country, more the ability of it to spend money on electricity consumption. Electricity consumption per capita rate in Africa was about $483 \mathrm{kwh}$ in 2014 , which is among the lowest in developing world. This is equal to electricity needed to power a 50-W light bulb in a year. Even if Africa achieves universal access, many people cannot still afford electrical gadgets to utilize the electricity generated and higher tariffs.
In view of this, there is a need to scale up wind energy, which is cheaper than fossil fuels. Wind energy development helps improve the economic well-being of rural dwellers, by increasing their earnings levels and employing more labor in the primary sector (Du and Takeuchi 2019). Marques et al. (2010) argued that higher income or GDP means two things: the ability to bear regulatory costs, in the forms of fiscal measures and market costs, and the ability to spend more on alternative energies.

Energy use in a country is expected to have a direct link with overall wind capacity addition. It explains the various sectors of the economy, such as commercial, residential, transportation, and industrial consumption of energy. Zhao et al. (2020) argued that other than pricing and non-pricing factors, power demand, wind resources, and technology have a significant correlation with power development in China. Most African countries have high energy demand as a result of increasing population and urbanization. This makes it imperative for more energy to meet the demands of the populace. This, therefore, means diversifying the generation mix to include wind and other cheaper sources to meet this growing demand. More so, wind and solar PV energy are projected to become profitable to 2030, even without subsides (Bertsch and Di Cosmo 2018), making it profitable for private sector investment in the wind industry.

\section{Country-specific factors}

Wind energy is a nascent industry on the African continent. For it to mature and enjoy the economies of scale, the sector has to be de-risked by instituting regulations that compensate for risks and entice private sector investments (Bertsch and Di Cosmo 2018). Kenya, together with the African Development Bank (AfDB) and a private developer, built the largest wind farm on the continent on Lake Turkana. It was achieved through private and public participation (Kazimierczuk 2019). By 2030, newly build wind farms would cost less than fossil fuel plants, establishing a tipping point for renewables (McKinsey and Company 2019). Africa has to join the bandwagon and have a piece of the pie. Eight African countries are counted as the world's well-endowed wind resource countries (Mukasa et al. 2015). Yet the industry is still underdeveloped. A study by Shrimali, Lynes, and Indvik (2015) asserted that the production credit is effective in scaling up the deployment of wind energy at the state level in the USA by $1.4 \mathrm{GW}$ annually.

African countries generate about $81 \%$ of electricity from thermal sources ("GWEC Africa Wind Energy Handbook," 2018). This makes it expensive for electricity generation and places a burden on consumers. Because most of them are independent power producers, they would pass the costs on to consumers in the form of higher tariffs. This, therefore, calls for substituting fossil fuels for renewables. In justifying the costly nature of generating power from fossil fuel sources, 
Katuri (2018) found that the equity to debt ratio of $80 \%$ debt and $20 \%$ equity is a financial burden on the neck of operating thermal plants, due to the incidence of high debt on the capital structure. For instance, Ghana projects to spend a billion dollars in operating its thermal plants in 2019 (Plan 2019). Ghana generates about $69.3 \%$ of its electricity from thermal sources (Government of Ghana, 2019). The relationship between the variable and wind capacity is anticipated to an inverse one. Table 2 shows the argument regarding variables.

\section{Data and methodology}

The study uses panel regression to rigorously analyze the relationship between wind capacity additions in African countries and polices variables that would influence this relationship. For this purpose, country level data from 2008 to 2017 is used and country level individual fixed effects model and panel data models applied. Panel data models describe individual behavior both across time and across the individual. Thus, panel data controls for individual country level heterogeneity. It is important to consider the quality of the work being done to ensure the right interpretation of the regression output. As a result, the things that would have an impact are taken care (Khandker, 2005). The fixed effect could be used due to the fact the unobserved heterogeneity is constant overtime. A panel data fixed effects' specification assumes that there is unobserved heterogeneity across individual countries captured in a model by the inclusion of an intercept term, that is, individual fixed effects are the remainder of variation in the regressand variable that cannot be explained by the regressors. Panel data is used to test the hypothesis that wind capacity addition in African countries is related to unobserved and observed heterogeneity in determining wind capacity addition in Africa. The unobserved variables are called fixed effects. Thus, panel data is used to derive consistent estimates of the coefficients of the parameters. In view of this, the country level fixed effect is important to control unobserved heterogeneity that also affects wind energy development in Africa (Olanrewaju et al. 2019) (Ogbe and Ogbe 2018) (Kilinc-ata 2016) (Panse and Kathuria 2016).The regression equation is given in the

WINDCAPA $=f($, gdpgwrth, resxhydro, energyuse, energyimport,

electricrate, electricconsu, $\mathrm{CO} 2$, electfrmfssfuel )

Equation (1) can be written as a panel model:

Windcap $_{i t} X_{i t}+\varepsilon_{i t}$

Specification of the stochastic term:

$\varepsilon_{i t}=a_{i}+\gamma+n_{i t}$

where $a_{i}$ is the unobserved cross-section time-specific effects, $\gamma$ is unobservable specific effects, and $n_{i t}$ is the mutual cross section time affects series

From Eq (2), $X_{i t}$ contains the variables to be used on the model.

Where

$$
\begin{aligned}
\text { WindcapaA }_{i t} & =\beta_{0}+\beta_{1} \text { gdpgwrth }+\beta_{2} \text { resxhydro }+\beta_{3} \text { energyuse } \\
& +\beta_{4} \text { energyimport }+\beta_{5} \text { electricrate }+\beta_{6} \text { electricconsu } \\
& +\beta_{7} \operatorname{co} 2+\beta_{8} \text { electfrmfssfuel } D \beta_{9+} D \beta_{10+} D \beta_{11}+\varepsilon_{i t}
\end{aligned}
$$

Equation (3) is written in its logarithmic form as below:

$$
\begin{aligned}
\text { LnWindcapa }_{i t}= & \beta_{0}+\ln \beta_{1} \text { gdpgwrth }+\ln \beta_{2} \text { resxhydro } \\
& +\ln \beta_{3} \text { energyuse }+\ln \beta_{4} \text { energyimport } \\
& +\ln \beta_{5} \text { electricrate }+\ln \beta_{6} \text { electricconsu } \\
& +\ln \beta_{7} \operatorname{co} 2+\ln \beta_{8} \text { electfrmfssfuel } \\
& +D \beta_{9+} D \beta_{10+} D \beta_{12+} \varepsilon_{i t}
\end{aligned}
$$

where

LnWindcapa $=$ wind capacity in each country measured in MW

gdpgwrth = gross domestic product growth in each country measured in $(\%)$

Resxhydro = electricity capacity excluding measured in Gigawatts (GWh)

Energyuse $=$ energy use is measured in $\mathrm{GWh} /$ capita

Energyimport $=$ thousand barrels per day

Electricrate $=$ electrification rate measured in $(\%)$

Electricconsu $=$ electricity consumption billion kwh

$\mathrm{CO} 2=$ metric tons per capita

electfrmfssfuel $=$ electricity production from fossil fuel sources is measured in $\mathrm{GWh} /$ capita

$D 10_{i}=$ dummy for tax incentives

$D 11_{i}=$ dummy for feed in tariffs

$\beta_{0}=$ the constant term

$\beta_{0} \ldots \ldots . . \beta_{11}$ are the coefficients of the model

$\varepsilon_{i t}=$ the stochastic term, depicts other variables that determine wind energy addition in Africa but were not captured in the analysis

Where $i=1 \ldots \ldots 11 t=2008, \ldots .2017$.

The similar approach adopted by Thapar et al. (2018); Menz and Vachon (2006); and Shrimali et al. (2015) for their panel set of data to investigate the relation of production tax credit with wind energy promotion. 
Table 2 Argument regarding the variables

\begin{tabular}{llll}
\hline Explanatory variable & Category & Positive/negative & Reason/argument \\
\hline Electrification rate & Increase it rapidly & Positive & Increase \\
GDP & Socioeconomics & Positive & Wind energy is best \\
Energy consumption & & Positive & Wind is cheaper \\
Electricity combustible fuels & & Negative & Ditch fossil fuels for wind \\
Energy import & Security variables & Negative & Change for wind energy \\
Energy use & & Negative & Pursue wind energy \\
& & & Wind emit zero CO 2 \\
$\mathrm{CO}_{2}$ emission & Socioeconomic variable & Positive & Increase RES generation \\
$\mathrm{RES} \mathrm{Electricity} \mathrm{X} \mathrm{hydro}$ & & Positive & \\
\hline
\end{tabular}

\section{Data}

A panel data of 17 countries in Africa with wind energy generation into the national grids were collected from 2008 to 2017 . With about 170 observations were collected from different sources. The dependent variable is wind capacity addition in the 17 countries with installed wind generation. The explanatory variables were categorized into socioeconomic, country specific, and policy variables. The data was sourced from the World Bank and the International Renewable Energy Agency 2017, as well as the United Nations Statistics system. The 17 countries from Africa were selected because they generate electricity from utility wind sources since 2008, which was the base year for this study. A similar approach was done by Shrimali et al. (2015) on the state level in the USA. After conducting Hausman test and the BreuschPagan Lagrange Multiplier test, the fixed effects were the preferred model for the analysis. Thus, it provided consistent coefficients to the estimators. The detail of dependent and independent variable is shown in Table 1 along with their descriptive statistics.

\section{Results and discussions}

The analysis of panel data results using fixed effect are shown in Table 4, the descriptive statistics are shown in Table 3.

After running the panel, data by applying Stata, the results of the fixed effects on the three thematic areas of socioeconomic, environment, and country-specific variables, under twelve explanatory variables including dummies has been generated. Here, six of the regressors were significant, and the rest were not significant in determining the development of wind energy in Africa. From the results arrived at, after conducting the analysis, it was realized that a socioeconomic variable of GDP is highly significant, explaining a strong correlation with wind energy capacity development in Africa. It has a $p$ value of $0.005 \%$. However, the relationship to wind capacity development is a negative one, with a coefficient value of $[-0.340]$. It indicates a negative relationship with wind capacity development. As wind GDP increases, wind capacity addition reduces, $[-0.340 \mathrm{MW}]$.This is against an orthodox economics theory that energy and GDP growth tend to go in tandem with an increase in energy consumption. However, the UK is one economy that decoupled its energy consumption for about a decade and albeit a growth trajectory in its GDP (National Statistics 2019)(Syed 2019).This is due to the fact that the structure of the economy has been changed over the years. The UK has outsourced its energy intensive industries. Another developing country that has reduced its energy intensity and yet increased its GDP over the years is Macau, a special administrative region of China. It has 761 Btu per dollar of GDP, yet it has one of the highest GDPs per capita in the world with $\$ 133,341$ in 2015 . The country's economy is dominated by the services sector, which is not energy intensive like steel and manufacturing (Phew research, 15). Ameen and Lalk (2019) used same method to study the development of wind energy in two Sub-Saharan Africa countries concluded the GDPs of Namibia and Mozambique have a direct correlation with wind energy development. This study is in line with the orthodox economic theory that GDP growth and energy demand move in sync. On the other hand, another environmental variable, electricity generation from renewable sources, excluding hydro, were not significant in determining wind capacity addition in Africa.

It has also been observed that other renewable sources for electricity generation instead of hydro have no impact on the wind based electricity addition in African continent. Furthermore, energy security variable like energy use is equally significant in determining the development of wind energy capacity in Africa. It came out significant after the analysis, with a $p$ value of 0.090 . This explains the various sectors of the economy and how they consume energy, that is, residential, commercial, transportation, and industry. Thus, it stands to reason that if all these sectors that form the nucleus of energy consumption are significant, then, there is the need to scale up wind energy in Africa for their consumption. The 
Table 3 Descriptive Statistics

\begin{tabular}{|c|c|c|c|c|c|c|c|}
\hline Variable & Definition & Source & Obs & Mean & Std.Dv. & Min & $\operatorname{Max}$ \\
\hline Lnwindcapa & Wind capacity(MW) & IRENA & 163 & 2.213 & 2.401 & 0 & 7.64 \\
\hline Lngdpgrowth & GDP growth rate (\%) & World Data Bank & 158 & 1.756 & 1.93 & -2.49 & 8.445 \\
\hline Lnresxhydro & $\begin{array}{l}\text { Electricity from non-hydro sources GWh capita } \\
\text { GWh/capita }\end{array}$ & World Data Bank & 168 & 6.392 & 1.489 & 0 & 8.448 \\
\hline Lnenergyuse & Energy use (GWh/capita) & World Data Bank & 170 & 3.869 & 1.265 & -0.844 & 6.263 \\
\hline lnenergyim $\sim \mathrm{t}$ & Share of electricity imports to consumption (\%) & World Data Bank & 81 & 3.726 & 1.14 & 1.519 & 6.019 \\
\hline lnelectric $\sim$ e & Electrification rate $(\%)$ & World Data Bank & 170 & 3.925 & 0.741 & 1.707 & 4.605 \\
\hline lnelectric $\sim \mathrm{u}$ & Energy consumption & World Data Bank & 170 & 5.701 & 2.533 & -2.408 & 8.448 \\
\hline $\operatorname{lnco} 2$ & $\mathrm{CO}_{2}$ emissions (metric tons per capita) & World Data Bank & 170 & 6.596 & 3.913 & -0.416 & 13.129 \\
\hline lnelectfrm $\sim 1$ & Electricity from fossil fuel & World Data Bank & 170 & 4.375 & 2.054 & -3.457 & 7.242 \\
\hline licensingD $\sim \mathrm{n}$ & Dummy & Dummy & 170 & 0.1 & 0.301 & 0 & 1 \\
\hline $\operatorname{Tax}$ & Dummy & Dummy & 170 & 0.1 & 0.301 & 0 & 1 \\
\hline est_re & Dummy & Dummy & 170 & 0.435 & 0.497 & 0 & 1 \\
\hline FITs & Dummy & Dummy & 170 & 0.1 & 0.301 & 0 & 1 \\
\hline _est_fe & & & 170 & 0.435 & 0.497 & 0 & 1 \\
\hline
\end{tabular}

correlation is a positive one. Hence, if energy use increases by $1 \mathrm{MW}$, wind capacity will increase by $0.238 \mathrm{MW}$. In addition, energy import was significant in determining the development of wind energy in Africa. It is an energy security variable which is significant with a probability value of 0.034 and also has a positive correlation, with a coefficient of $1.002 \%$. This implies that for every one thousand barrel of oil imported from a foreign country, about $0.034 \mathrm{MW}$ of wind power could be installed in Africa. A study by (Dong 2012) confirmed this assertion, where wind capacity addition has a direction relationship with net energy imports, showing that energy import helps in developing wind capacity in Africa. This was anticipated. It is plausible that as a country aims to be energy reliant and sufficient will not continue to import energy when it can develop its local resources like wind, which is cheaper and cleaner for its domestic consumption. This is true in developing Africa, where energy poverty is high and importbased energy consumption lead to fiscal imbalance as well as macroeconomic instability in many countries. A very curious result was obtained for electrification rate or energy access on the African continent. It was not significant. Also, its correlation with wind energy capacity addition is negative. As more than 600 million people have no access to electricity, Africa is considered least electrified continent of this plant.

Table 4 Regression results

\begin{tabular}{|c|c|c|c|c|c|c|c|}
\hline lnwindcapa & Coef. & St.Err & $t$ value & $p$ value & {$[95 \%$ Conf } & Interval] & Sig \\
\hline lngdpgrowth & -0.340 & 0.116 & -2.93 & 0.005 & -0.573 & -0.107 & $* * *$ \\
\hline lnresxhydro & 0.046 & 0.049 & 0.94 & 0.354 & -0.053 & 0.144 & \\
\hline lnenergyuse & 0.411 & 0.238 & 1.73 & 0.090 & -0.066 & 0.888 & $*$ \\
\hline lnenergyimport & 1.002 & 0.460 & 2.18 & 0.034 & 0.079 & 1.925 & $* *$ \\
\hline Inelectricrate & -0.250 & 0.629 & -0.40 & 0.693 & -1.511 & 1.011 & \\
\hline lnelectricconsu & 4.803 & 1.178 & 4.08 & 0.000 & 2.441 & 7.164 & $* * *$ \\
\hline $\operatorname{lnco} 2$ & -0.051 & 0.028 & -1.79 & 0.079 & -0.107 & 0.006 & $*$ \\
\hline Lnelectfrmfssfuel & -0.447 & 0.134 & -3.34 & 0.002 & -0.715 & -0.178 & $* * *$ \\
\hline LicensingDuration(Dummy) & 0.004 & 0.306 & 0.01 & 0.990 & -0.609 & 0.617 & \\
\hline FITs(Dummy) & -0.110 & 0.302 & -0.36 & 0.716 & -0.715 & 0.494 & \\
\hline Tax(Dummy) & -0.068 & 0.258 & -0.26 & 0.793 & -0.585 & 0.449 & \\
\hline Constant & -29.205 & 6.616 & -4.41 & 0.000 & -42.469 & -15.941 & $* * *$ \\
\hline Mean dependent var & 2.411 & & \multicolumn{2}{|c|}{ SD dependent var. } & 2.482 & & \\
\hline R-squared & 0.812 & & \multicolumn{2}{|c|}{ Number of obs } & 74.000 & & \\
\hline$F$-test & 21.138 & & \multicolumn{2}{|c|}{ Prob $>$ F } & 0.000 & & \\
\hline Akaike crit. (AIC) & 125.108 & & \multicolumn{2}{|c|}{ Bayesian crit. (BIC) } & 152.757 & & \\
\hline
\end{tabular}

$* * * p<0.01, * * p<0.05, * p<0.1$ 
This variable was expected to correlate directly with wind capacity addition. More so, electricity consumption was equally perfectly significant after the analysis. The probability value was perfect [0.000], suggesting a strong correlation between wind energy capacity addition and electricity consumption. The correlation is a direct one. The coefficient is [4.803 MW]. As electricity consumption increases, wind capacity addition increases. Of course, the variable that has dominated global political discourse, carbon dioxide (CO2) emissions have proven significant as was expected. $\mathrm{CO}_{2}$ is highly significant after the analysis, which shows deploying wind will abate $\mathrm{CO}_{2}$ emissions. It emits no $\mathrm{CO}_{2}$.

\section{Discussion}

On the policy front, the results from the regression were startling. The dummies for feed in tariffs, tax, and licensing duration were not significant in determining the development of wind energy in Africa. This confirms the early literature by Staid and Guikema (2013) and found that the key drivers of wind energy capacity development across the US are geographical and physical, other than policy drivers. Furthermore, Zachmann et al. (2014) argumented that, innovation polices like public research development and demonstration and subsidies (RD\&D) and deployment policies, would help in scaling up low-carbon technologies and that current wind deployment is as a result of RD\&D that interacted with best patenting. Another study that leads credence to this argument of Thapar et al. (2018) which used panel data to analyze 16 explanatory variables on India and concluded that FITs and renewal purchase obligation (RPO) are not significant in influencing the growth of wind energy in India. Indeed, to support this study notion that tax is insignificant in scaling up wind energy in Africa. It is not only economically sustainable, but it distorts the market fundamentals and strains the national grid as well (Tax Credit for Wind and Solar, 2019). Perhaps the reason could be attributed to the fact that most countries are now adopting a competitive auction system against FITs to deploying renewables. In 2018, 48 countries adopted auctions, including African countries, an increase from 29 in the previous year (REN21 2019).

The issue of climate change has dominated global discourse due to the negative impacts it has on the world, especially developing countries, rising temperatures, rising sea levels, hurricanes and typhoons, and the destruction of energy infrastructure(Cantelmo et al. 2019). All these are caused by a climate that results from $\mathrm{CO}_{2}$ emissions. Even though Africa's emission level is very negligible (Mukasa et al. 2015), the impacts of climate change are global. Notwithstanding, Africa is already at the receiving ends of climate change through natural disasters in Mozambique and Zimbabwe and Malawi, which could cost their GDPs growth by a percentage point and about $1.6 \%$ loss in their consumption, as natural disaster prone countries (Cantelmo et al. 2019).The power sector is the biggest emitter of $\mathrm{CO}_{2}$, and so decarbonizing the power sector through the adoption of wind energy would reduce $\mathrm{CO}_{2}$ emission and meet the Paris goals of limiting global temperature rise by $1.5^{\circ}$ pre-industrial levels (Chmi and Eea 2019). Obviously, another variable that came out significant was electricity from fossil fuel sources. Indicating it determines the level of wind energy capacity addition in Africa. This means that as electricity generation from fossil fuels increases, wind capacity addition decreases BY $0.447 \mathrm{MW}$. This is economically true. In that, the continued consumption of fossil fuels would not give priority to African countries to invest in wind energy. There has to be a substitution effect so as to scale up wind.

\section{Conclusion and policy implication}

The study examined the drivers to scaling up wind energy on the Africa continent, using three thematic variables of policy, socioeconomic, and energy security. Here a panel dataset used to analyze these variables at the country level. The study used the fixed effect mode to cater for time invariant heterogeneity among country and instrumental variables for policy to analyze the explanatory variables. Countries are 17 on the continent with utility-scale wind projects since 2008 . The results exhibit different effects of the policy variables. FITs, tax, and licensing duration were not significant in scaling wind capacity in Africa. The absence of effects of wind capacity addition in Africa, especially the tax element, is in tandem with the argument raised by Tax credit for Wind and Solar (2019) in the USA, where they contend that the production tax credit is not sustainable economically and distorts market fundamentals and at the time straining the grid. Africa can take a lesson from and avoid these pitfalls in structuring the tax system for the wind industry in Africa. This is in sharp contrast to the numerous studies that suggest FITs have effects on scaling up renewables capacity like wind (Menz and Vachon 2006; Case et al. 2010; Nicolini and Tavoni 2017; and Dong 2012). GDP was proved to have a significant effect of wind capacity addition on the continent but an inverse relationship. This was envisaged, but the correlation was not anticipated. Equally significant were $\mathrm{CO}_{2}$ emissions, energy use, and electricity consumption. All these variables point to a correlation to wind energy capacity in Africa.

An unanticipated result was that of the electrification rate in the analysis, which came out not significant. The fact that Africa has not electrified many households makes this result surprising. Electricity access is very important for Africa so to create and sustain economic growth and development. The absence of the predictive power of the variable was not expected. The reason behind this could be that the rest of the variables are more important in scaling up wind energy than that of 
electrification. As electricity from fossil fuel sources is significant, it suggests that more wind energy should be generated and ditch fossil fuels. Another insignificant variable that came out after the analysis was energy generation from renewables excluding hydro sources. It was an unexpected result, as well. This variable being renewable should be significant to boost the RES drive on the continent. Hydro was excluded because it does not enjoy subsidies from the state. Now, the policy implications emanating from this study are that:

1. The study concludes that there are other factors rather than a policy that drives wind energy capacity in Africa.

2. The wind industry in Africa could create well-paying jobs ranging from manufacturing to construction, operation, and maintenance, as the study found GDP growth to correlate positively with wind capacity addition.

3. Future wind energy deployment has to be institutionally, technically, and regionally integrated and modernized grids to take VRE and to achieve synergy. It would enable the access of national boundaries between energy sectors. The Africa Clean Energy Corridor is a laudable project in the right direction. In the West Africa Clean Energy Corridor (WACEC), countries like Ghana, Burkina Faso, Cote d'Ivoire, and Togo have started integrating their power infrastructure.

4. African countries need to halt granting subsidies to fossil fuel companies and divert for renewables. The environmental and economic costs of such subsidies are damning. In 2013, 30 SSA countries granted subsidies worth $\$ 32$ billion. Global subsidies to fossil fuel companies reached $\$ 300$ billion in 2017, twice the support for RES electricity generation.

5. Africa has to maximize public-private sector financing and leverage on the partnership to catalyze finances for scaling up wind energy deployment on the continent. There are a number of such projects on the continent between the African Development Bank (AfDB) and many countries; for instance, the Lake Turkana Wind Farm in Kenya and the Tangier projects in Morocco.

6. Finally, public research development and demonstration (RD\&D) is key to scaling wind energy in Africa. It should be within countries and regional blocs.

In conclusion, despite the robustness of the results, Africa faces many challenges in the energy sector after the COVID19 , such as the oil and gas boom and bust, climate change concerns, the need for governments to find stimulus packages to revamp their economies, and the growing acceptance of RES. Wind energy could come in handy in this regard to create jobs and shield the continent from economic headwinds. Future research could consider the impact of the COVID-19 on the wind industry in Africa. As this analysis is based to find the wind energy impact on African economy.
The limitation is that the wind energy industry in Africa is a nascent one, and there is a paucity of data and research regarding the wind energy drivers on the continent. Hence most references are research related to renewables in general.

\section{References}

Aguirre M, Ibikunle G (2014) Determinants of renewable energy growth : a global sample analysis 69:374-384

Ahmadi A, Jamali DH, Ehyaei MA, El Haj AM (2020) Energy, exergy, economic and exergoenvironmental analyses of gas and air bottoming cycles for production of electricity and hydrogen with gas reformer. J Clean Prod 259:120915. https://doi.org/10.1016/j. jclepro.2020.120915

Ahmed T, Bhatti AA (2019) Do power sector reforms affect electricity prices in selected Asian countries? Energy Policy 129:1253-1260. https://doi.org/10.1016/j.enpol.2019.03.012

Ameen AM, Lalk J (2019) Wind energy development in sub-Saharan Africa: application of the satsa framework. South African J Ind Eng 30:176-189. https://doi.org/10.7166/30-2-1962

AREI (2017) The Africa renewable Energy initiative - setting the context. $1-16$

Asbahi AAMHA, Gang FZ, Iqbal W et al (2019) Novel approach of principal component analysis method to assess the national energy performance via Energy Trilemma Index. Energy Rep 5:704-713. https://doi.org/10.1016/j.egyr.2019.06.009

Asim M, Saleem S, Imran M, Leung MKH, Hussain SA, Miró LS, Rodríguez I (2020) Thermo-economic and environmental analysis of integrating renewable energy sources in a district heating and cooling network. Energy Effic 13:79-100. https://doi.org/10.1007/ s12053-019-09832-9

Bertsch V, Di Cosmo V (2018) Are renewables profitable in 2030? A Comparison between Wind and Solar Across Europe SSRN Electron J https://doi.org/10.2139/ssrn.3241987

Bublitz A, Keles D, Zimmermann F, Fraunholz C, Fichtner W (2019) A survey on electricity market design: insights from theory and realworld implementations of capacity remuneration mechanisms. Energy Econ 80:1059-1078. https://doi.org/10.1016/j.eneco.2019. 01.030

Cantelmo A, Melina G, Papageorgiou C (2019) Macroeconomic outcomes in disaster-prone countries. IMF Work Pap 19:. https://doi. org/10.5089/9781513515380.001

Case TE, Cansino JM, Pablo-Romero MP (2010) Taxes Incentives to Promote Res Deployment :

Chen L, Xu L, Yang Z (2017) Accounting carbon emission changes under regional industrial transfer in an urban agglomeration in China's Pearl River Delta. J Clean Prod 167:110-119. https://doi. org/10.1016/j.jclepro.2017.08.041

Chmi S, Eea MT (2019) Renewable energy in Europe - 2019

Cox S, Tegen S, Baring-Gould I, et al (2015) Policies to support wind power deployment: key considerations and good practices. Clean Energy Solut Cent 24

Dong CG (2012) Feed-in tariff vs . renewable portfolio standard : an empirical test of their relative effectiveness in promoting wind capacity development. Energy Policy 42:476-485. https://doi.org/10. 1016/j.enpol.2011.12.014

$\mathrm{Du}$ Y, Takeuchi K (2019) Can climate mitigation help the poor ? Measuring impacts of the CDM in rural China it. J Environ Econ Manag 95:178-197. https://doi.org/10.1016/j.jeem.2019.03.007

Eberhard A, Dyson G (2020) What is the impact of investing in power? 
Edenhofer O, Flachsland C, Kalkuhl M, et al (2019) Assessment of the German climate package and next steps

Eickemeier P, Schlömer S, Farahani E, et al (2014) Climate change 2014 mitigation of climate change working group III contribution to the fifth assessment report of the intergovernmental panel on climate change

Iqbal N, Mohsin M (2019) Assessing social and financial efficiency: the evidence from microfinance institutions in Pakistan Muhammad Sajid Tufail (corresponding author)

Iqbal W, Yumei H, Abbas Q, Hafeez M, Mohsin M, Fatima A, Jamali M, Jamali M, Siyal A, Sohail N (2019) Assessment of wind energy potential for the production of renewable hydrogen in Sindh Province of Pakistan. Processes 7. https://doi.org/10.3390/ pr7040196

Iram R, Zhang J, Erdogan S, Abbas Q, Mohsin M (2019) Economics of energy and environmental efficiency: evidence from OECD countries. Environ Sci Pollut Res 27:3858-3870. https://doi.org/10.1007/ s11356-019-07020-x

International Renewable Energy Agency (IRENA) (2017) Renewable energy auctions

IRENA (2018) Renewable Energy outlook: Egypt

IRENA (2019) Renewable capacity statistics 2019, International Renewable Energy Agency (IRENA), Abu Dhabi

Jewell J, Vinichenko V, McCollum D, Bauer N, Riahi K, Aboumahboub T, Fricko O, Harmsen M, Kober T, Krey V, Marangoni G, Tavoni M, van Vuuren DP, van der Zwaan B, Cherp A (2016) Comparison and interactions between the long-term pursuit of energy independence and climate policies. Nat Energy 1. https://doi.org/10.1038/ nenergy.2016.73

Katuri PK (2018) Profitability analysis of thermal power plant a case study. 118:1-8

Kazimierczuk AH (2019) Wind energy in Kenya : a status and policy framework review. Renew Sust Energ Rev 107:434-445. https:// doi.org/10.1016/j.rser.2018.12.061

Kilinc-ata N (2016) Energy for sustainable development the evaluation of renewable energy policies across EU countries and US states : an econometric approach. Energy Sustain Dev 31:83-90. https://doi. org/10.1016/j.esd.2015.12.006

Komendantova N, Schinko T, Patt A (2019) De-risking policies as a substantial determinant of climate change mitigation costs in developing countries: case study of the Middle East and north African region. Energy Policy 127:404-411. https://doi.org/10.1016/j.enpol. 2018.12.023

Lucas PL, Nielsen J, Calvin K, et al (2015) Future energy system challenges for Africa : Insights from Integrated Assessment Models 86: 705-717. https://doi.org/10.1016/j.enpol.2015.08.017

Marques C, Fuinhas A, Manso JRP (2010) Motivations driving renewable energy in European countries : a panel data approach 38:68776885. https://doi.org/10.1016/j.enpol.2010.07.003

McKinsey \& Company (2019) Global Energy Perspective 2019: Reference Case. Energy Insights 31

Menz FC, Vachon S (2006) The effectiveness of different policy regimes for promoting wind power : experiences from the states 34:17861796. https://doi.org/10.1016/j.enpol.2004.12.018

Moerenhout TSH, Sharma S, Urpelainen J (2019) Commercial and industrial consumers' perspectives on electricity pricing reform: evidence from India. Energy Policy 130:162-171. https://doi.org/10. 1016/j.enpol.2019.03.046

Mohsin M, Rasheed AK, Saidur R (2018a) Economic viability and production capacity of wind generated renewable hydrogen. Int J Hydrog Energy 43:2621-2630

Mohsin M, Zhou P, Iqbal N, Shah SAA (2018b) Assessing oil supply security of South Asia. Energy 155:438-447. https://doi.org/10. 1016/j.energy.2018.04.116

Mohsin M, Abbas Q, Zhang J, Ikram M, Iqbal N (2019a) Integrated effect of energy consumption, economic development, and population growth on $\mathrm{CO} 2$ based environmental degradation: a case of transport sector. Environ Sci Pollut Res 26:32824-32835. https://doi.org/ 10.1007/s11356-019-06372-8

Mohsin M, Rasheed AK, Sun H, Zhang J, Iram R, Iqbal N, Abbas Q (2019b) Developing low carbon economies: an aggregated composite index based on carbon emissions. Sust Energy Technol Assess 35:365-374. https://doi.org/10.1016/j.seta.2019.08.003

Mohsin M, Zaidi U, Abbas Q et al (2019c) Relationship between multifactor pricing and equity price fragility: evidence from Pakistan. Int J Sci Technol Res 8:434-442

Mohsin M, Zhang J, Saidur R, Sun H, Sait SM (2019d) Economic assessment and ranking of wind power potential using fuzzy-TOPSIS approach. Environ Sci Pollut Res 26:22494-22511. https://doi.org/ 10.1007/s11356-019-05564-6

Morales L, Hanly J (2018) European power markets-a journey towards efficiency. Energy Policy 116:78-85. https://doi.org/10.1016/j. enpol.2018.01.061

Mukasa AD, Mutambatsere E, Arvanitis Y, Triki T (2015) Wind energy in sub-Saharan Africa: financial and political causes for the sector's under-development. Energy Res Soc Sci 5:90-104. https://doi.org/ 10.1016/j.erss.2014.12.019

Mustapha T, Gauri S, Gürbüz G (2015) Mauritania: renewables readiness assessment. 1:192. https://doi.org/10.1787/aeo-2013-10-en

National Statistics (2019) Energy consumption in the UK ( ECUK ) 1970 to 2018. Dep Business, Energy Ind Strateg 10

Nicolini M, Tavoni M (2017) Are renewable energy subsidies effective ? Evidence from Europe. Renew Sust Energ Rev 74:412-423. https:// doi.org/10.1016/j.rser.2016.12.032

Ogbe W, Ogbe W (2018) Determinants of renewable energy growth in Sub-Saharan Africa : https://doi.org/10.1016/j.energy.2018.05.068

Olanrewaju BT, Olubusoye OE, Adenikinju A, Akintande OJ (2019) A panel data analysis of renewable energy consumption in Africa. Renew Energy 140:668-679. https://doi.org/10.1016/j.renene. 2019.02.061

Olsen KP, Zong Y, You S, Bindner H, Koivisto M, Gea-Bermúdez J (2020) Multi-timescale data-driven method identifying flexibility requirements for scenarios with high penetration of renewables. Appl Energy 264:114702. https://doi.org/10.1016/j.apenergy.2020. 114702

Panse R, Kathuria V (2016) Role of policy in deployment of wind energy: evidence across states of India. Renew Sust Energ Rev 53:422-432. https://doi.org/10.1016/j.rser.2015.08.056

Panse R, Kathuria V (2018) What explains investment-resource gap in wind power technology in India? Testing for the relevance of local factors. Renew Sust Energ Rev 82:1514-1527. https://doi.org/10. 1016/j.rser.2017.06.003

Plan S (2019) Electricity supply Plan

Principle F, Practice TO (2019) Fiscal policies for paris climate strategies

Purohit P, Michaelowa A (2007) CDM potential of wind power projects in India

REN21 (2019) REN21-2019 Global Status Report

Sei ML, Sei CML, Sei PE (2016) How additional is the clean development mechanism?

SEWEA (2019) South Africa's utility-scale wind \& re industry key data as at March 2019. 1-2

Shami SH, Ahmad J, Zafar R, Haris M, Bashir S (2016) Evaluating wind energy potential in Pakistan's three provinces, with proposal for integration into national power grid. Renew Sust Energ Rev 53: 408-421. https://doi.org/10.1016/j.rser.2015.08.052

Shrimali G, Lynes M, Indvik J (2015) Wind energy deployment in the US: An empirical analysis of the role of federal and state policies. Renew Sust Energ Rev 43:796-806. https://doi.org/10.1016/j.rser. 2014.11.080 
Staid A, Guikema SD (2013) Statistical analysis of installed wind capacity in the United States. Energy Policy 60:378-385. https://doi.org/ 10.1016/j.enpol.2013.05.076

Sun H, Ikram M, Mohsin M, Abbas Q (2019a) Energy security and environmental efficiency: evidence from OECD countries. Singap Econ Rev:1-18. https://doi.org/10.1142/S0217590819430033

Sun H-P, Tariq G, Haris M, Mohsin M (2019b) Evaluating the environmental effects of economic openness: evidence from SAARC countries. Environ Sci Pollut Res 26:24542-24551. https://doi.org/10. 1007/s11356-019-05750-6

Sun H, Mohsin M, Alharthi M, Abbas Q (2020a) Measuring environmental sustainability performance of South Asia. J Clean Prod 251: 119519. https://doi.org/10.1016/j.jclepro.2019.119519

Sun L, Qin L, Taghizadeh-Hesary F, Zhang J, Mohsin M, Chaudhry IS (2020b) Analyzing carbon emission transfer network structure among provinces in China: new evidence from social network analysis. Environ Sci Pollut Res. https://doi.org/10.1007/s11356-02008911-0

Syed A (2019) The decoupling of economic growth from carbon emissions: UK evidence. Off Natl Stat 1-24

Texas U of (2019) Tax credits for wind and solar
Thapar S, Sharma S, Verma A (2018) Key determinants of wind energy growth in India: analysis of policy and non-policy factors. Energy Policy 122:622-638. https://doi.org/10.1016/j.enpol.2018.08.004

Zachmann G, Serwaah A, Peruzzi M (2014) When and how to support renewables? LETTING THE DATA SPEAK

Zhang S, Andrews-Speed P, Li S (2018) To what extent will China's ongoing electricity market reforms assist the integration of renewable energy? Energy Policy 114:165-172. https://doi.org/10.1016/j. enpol.2017.12.002

Zhao X, Li S, Zhang S, Yang R, Liu S (2020) The effectiveness of China â€TM s wind power policy : an empirical analysis. Energy Policy 95:269-279. https://doi.org/10.1016/j.enpol.2016.04.050

Zhou Y, Kong Y, Zhang T (2020) The spatial and temporal evolution of provincial eco-efficiency in China based on SBM modified threestage data envelopment analysis. Environ Sci Pollut Res 27:85578569. https://doi.org/10.1007/s11356-019-07515-7

Publisher's note Springer Nature remains neutral with regard to jurisdictional claims in published maps and institutional affiliations. 